\title{
Preliminary results of the effect of dietary energy and protein levels on the production of female breeding Ostriches
}

\author{
Z. Brand ${ }^{1}$, T.S. Brand ${ }^{2}$, C.R. Brown ${ }^{3}$ and S.J. van Schalkwyk ${ }^{1}$ \\ ${ }^{1}$ Little Karoo Agriculture Development Centre, P.O. Box 351, Oudtshoorn, 6620, South Africa; ${ }^{2}$ Elsenburg Agricultural \\ Development Institute, Private Bag X1, Elsenburg, 7607, South Africa; ${ }^{3}$ Department of Zoology and Entomology, Rhodes \\ University, Grahamstown, 6139, South Africa.
}

\section{Introduction}

Limited information is the main reason for the ineffective feeding of ostriches during the breeding season. The trend in the past was to feed breeding female ostriches diets with high energy and protein levels to elevate production, but this had the opposite effect. The aim of this study was determine production responses to different levels of protein and energy in breeding ostriches.

\section{Materials and Methods}

The experimental birds used in the study were obtained from the commercial ostrich breeding flock at the Klein Karoo Agricultural Development Centre near Oudtshoorn. The management of the breeding flock and the treatment of the eggs were described by Van Schalkwyk et al. (1996). Van Schalkwyk et al. (1998) described the collection and subsequent treatment and incubation of eggs. Ninety pairs of adult breeding ostriches were randomly divided into nine groups of ten pairs per group. Birds were fed dietary energy levels of $7.5 \mathrm{MJ} / \mathrm{kg}$, 8.5 $\mathrm{MJ} / \mathrm{kg}$ or $9.5 \mathrm{MJ} / \mathrm{kg}$ and protein levels of $10 \%, 12 \%$ or $14 \%$ during the breeding season (June-January). The formulation and composition of the diet is given in the accompanying abstract (Brand et al., 2000a) on male breeders. Measurements were done at the onset and at the end of the breeding season.

\section{Results and Discussion}

Table 1 The effect of dietary energy levels on the production of female ostriches (mean \pm SE)

\begin{tabular}{|c|c|c|c|c|}
\hline \multirow[t]{2}{*}{ Measurement } & \multicolumn{3}{|c|}{ Energy level (MJ/kg) } & \multirow{2}{*}{$\begin{array}{l}\text { Level of } \\
\text { significance } \\
\text { (P) }\end{array}$} \\
\hline & 7.5 & 8.5 & 9.5 & \\
\hline Starting mass $(\mathrm{kg})$ & $119.9 \pm 2.9$ & $116.5 \pm 2.9$ & $117.7 \pm 2.9$ & 0.678 \\
\hline End mass $(\mathrm{kg})$ & $95.7 \pm 2.6^{\mathrm{a}}$ & $102.1 \pm 2.6 b^{b}$ & $103.9 \pm 2.6^{\mathrm{b}}$ & 0.065 \\
\hline Mass change $(\mathrm{kg})$ & $-24.2 \pm 1.9^{\mathrm{a}}$ & $-14.4 \pm 1.9^{\mathrm{b}}$ & $-13.8 \pm 1.9^{\mathrm{b}}$ & 0.001 \\
\hline Egg production (n) & $38.1 \pm 4.0^{\mathrm{a}}$ & $50.9 \pm 4.0^{\mathrm{b}}$ & $55.2 \pm 4.0^{\mathrm{b}}$ & 0.009 \\
\hline Chicken production (n) & $21.1 \pm 3.2^{\mathrm{a}}$ & $22.7 \pm 3.2^{\mathrm{a}}$ & $33.1 \pm 3.2^{\mathrm{b}}$ & 0.016 \\
\hline Infertile eggs ${ }^{+}$ & $20.6 \pm 4.2$ & $26.8 \pm 4.2$ & $15.5 \pm 4.2$ & 0.144 \\
\hline Embryonic deaths ${ }^{+}$ & $18.7 \pm 2.3$ & $20.1 \pm 2.3$ & $19.5 \pm 2.3$ & 0.894 \\
\hline Live chicks hatched & $54.9 \pm 4.5$ & $45.3 \pm 4.5$ & $57.2 \pm 4.5$ & 0.124 \\
\hline
\end{tabular}

Main effects only are presented, as no significant interactions were observed. The starting mass of the birds did not differ significantly between dietary treatments. The end mass for the $7.5 \mathrm{MJ}$ energy level and $10 \%$ protein level differed significantly ( $\mathrm{P} \leq 0.05$ ) from that of the $8.5 \mathrm{MJ}$ and $9.5 \mathrm{MJ}$ energy and $12 \%$ protein level. The egg production results show a significant difference $(\mathrm{P}<0.05)$ between the lowest energy level of $7.5 \mathrm{MJ}$ and that of the $8.5 \mathrm{MJ}$ and $9.5 \mathrm{MJ}$ level. There was no significant difference in egg-production between energy levels $8.5 \mathrm{MJ}$ and 9.5 MJ or between the different protein levels. A significant difference $(\mathrm{P}<0.05)$ was found in chicken production between energy levels 7.5 MJ, 8.5 MJ and that of energy level 9.5 MJ. The different levels of protein had no effect on the egg-production or chicken production. Neither the energy levels nor the protein levels of the diets had any significant effect on infertile eggs, embryonic deaths or live chicks hatched. 
(c) South African Society of Animal Science

Short paper and poster abstracts: $38^{\text {th }}$ Congress of the South African Society of Animal Science

Table 2 The effect of dietary protein on the production of female ostriches (mean $\pm \mathrm{SE}$ )

\begin{tabular}{lcccc}
\hline Measurement & \multicolumn{3}{c}{ Protein, \% } & \begin{tabular}{c} 
Level of \\
significance \\
\cline { 2 - 4 }
\end{tabular} \\
\cline { 2 - 4 }$(\mathrm{P})$
\end{tabular}

\section{Conclusion}

Egg-production and chicken production were significantly lower on the lower energy levels. These preliminary results indicate that $7.5 \mathrm{MJ}$ is the minumum energy level. Egg-production and chicken production were not affected by protein level.

\section{References}

Brand, Z., Brand, T.S., Brown, C.R. and Van Schalkwyk, S. J., 1999. Preliminary results of the effect of dietary energy and protein levels on production of breeding ostriches. Proc. $37^{\text {th }}$ Conf. Soc. Anim. Prod., p. 22.

Brand, Z., Brand, T.S., Brown, C.R. and Van Schalkwyk, S J., 2000. Preliminary results on the effect of dietary energy and protein levels on the production of male breeding ostriches. S. Afr. J. Anim. Sci. 30,

Van Schalkwyk, S.J., Cloete, S.W.P., and De Kock, J.A., 1996. Repeatability and phenotypic correlation for bodyweight and reproduction in commercial ostrich breeding pairs. Brit. Poultr. Sci., 37, 953-962. 